\title{
Constrictive pericarditis associated with an ascending aortic aneurysm and aortic valve insufficiency
}

\author{
Krzysztof Jarmoszewicz, Jan Rogowski \\ Department of Cardiac and Vascular Surgery, Medical University in Gdansk \\ Kardiochirurgia i Torakochirurgia Polska 2014; 11 (2): 200-201
}

\begin{abstract}
We report the case of a 54-year-old patient who was admitted to our institution for planned surgical treatment of an ascending aortic aneurysm and aortic valve insufficiency. A decision was made to perform an elective Bentall-de Bono procedure. Constrictive pericarditis was revealed intraoperatively. The Bentall-de Bono procedure and the resection of calcified pericardium were performed successfully.

Key words: pericarditis, constrictive.
\end{abstract}

\section{Case study}

The patient, aged 54, was admitted to the clinic for planned surgical treatment of an ascending aortic aneurysm with substantial aortic valve insufficiency. His medical history included previous pericarditis (several years before, no hospital records available), without any other significant chronic conditions. For the past several months, the patient had been experiencing a reduction in exercise capacity, which prompted him to seek medical attention. Echocardiography revealed significant aortic insufficiency with vena contracta of $7 \mathrm{~mm}$ and substantial dilatation of the ascending aorta - up to $6 \mathrm{~cm}$; cardiac cavity dimensions were normal, and ejection fraction was estimated at $60 \%$. Coronarography did not reveal any significant changes in the coronary vessels. The conducted radiological examination of the lungs demonstrated clear calcifications overlapping the cardiac shadow. The conducted physical examination revealed an enlarged liver as well as slight edemas on the lower extremities.

The patient underwent a planned Bentall-de Bono procedure, conducted under general anesthesia. After the chest was opened via median sternotomy, a significantly thickened and calcified pericardium was revealed, covering the anterior and inferior cardiac surface, primarily over the right ventricle and the right atrium. The calcified pericardium was gradually separated by sharp dissection, freeing the heart completely. The intraoperative

\section{Streszczenie}

W pracy przedstawiono przypadek 54-letniego chorego przyjętego do kliniki celem wykonania planowej operacji z powodu tętniaka aorty wstępującej i niedomykalności zastawki aortalnej, u którego śródoperacyjnie stwierdzono zaciskające zapalenie osierdzia. Przeprowadzono z powodzeniem zabieg metodą Bentalla-de Bono, usuwając jednocześnie zwapniałe osierdzie.

Słowa kluczowe: zaciskające zapalenie osierdzia.

photograph presents the partially dissected calcified pericardium (Fig. 1). Additionally, on the inferior cardiac surface below the pericardium, there was a large reservoir filled with a whitish greasy substance, which was drawn for bacteriological and tuberculosis testing. Dissecting the coronary openings, especially in the case of the right coronary artery, proved particularly challenging. Subsequently, heparin was administered, extracorporeal circulation was started with aortic arch and right atrial cannulation, and the heart was stopped with crystalloid cardioplegia under moderate hypothermia. This was followed by the implantation of a St. Jude valve conduit with the Bentall-de Bono method. After the patient's body temperature was raised and reperfusion was performed, the extracorporeal circulation was stopped, and the heart resumed its hemodynamic function without any complications. After hemostasis was achieved, the chest was closed in a typical fashion, and drainage was maintained. The postoperative course was uneventful, and the bacteriological examination of the intraoperative material was negative. On the $7^{\text {th }}$ day, the patient was discharged from the clinic in good general condition and was referred to the cardiac ward for further treatment. During a follow-up visit 4 weeks after the surgery, the patient reported a significant improvement in exercise capacity. Cardiac echo showed no significant deviations. 


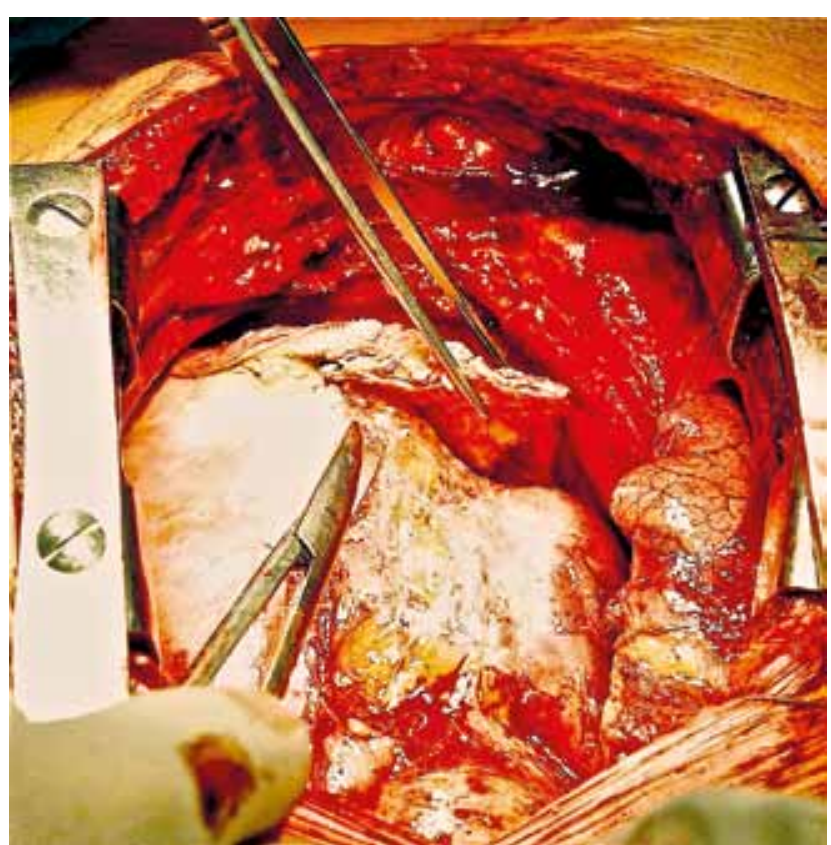

Fig. 1. Intraoperative image. The heart and the partially dissected calcified pericardium

\section{Discussion}

The most frequent cause of constrictive pericarditis is tuberculosis infection. In the medical literature it is estimated to cause between $38 \%$ and $83 \%$ of cases [1-3]. Nonspecific viral and bacterial pericardial infections constitute the second most frequent group of diseases which may lead to constrictive pericarditis [4]. The rising significance of radiotherapy due to neoplastic disease and previous cardiac surgery procedures in the etiology of this condition has been observed in recent years [4]. Tuberculotic etiology was not confirmed in our patient; we suspect that the previous pericarditis was of non-specific infectious etiology, which consequently led to constrictive pericarditis within a relatively short period of time (2 years).

The clinical signs presented by the patient, who complained mostly of a gradual but significant decrease in exercise capacity, were linked to aortic insufficiency; as a result, the patient's condition was not diagnosed even though imaging examinations (lung X-ray) described clear calcifications overlapping the cardiac shadow. Even the peripheral edemas and the enlarged liver, signs more specific to constrictive pericarditis, did not raise any suspicion that another cause of the signs of circulatory insufficiency may exist alongside the evident pathology of the aorta and aortic valve. The presented case may serve as a warning, so that we do not focus exclusively on what is obvious in the clinical picture of the patient, but that we also take other, less common diseases into consideration, especially if basic tests provide us with indications concerning the diagnosis.

\section{References}

1. Bozbuga N, Erentug V, Eren E, Erdogan HB, Kirali K, Antal A, Akinci E, Yakut C. Pericardiectomy for chronic constrictive tuberculous pericarditis. Tex Heart Inst J 2003; 30: 180-185.

2. Raffa H, Mosier J. Constrictive pericarditis in Saudi Arabia. East Africa Med J 1990; 67: 609-613.

3. Afzal A, Keohane M, Keeley E, Borzak S, Callender CW, lannuzzi M. Myocarditis and pericarditis with tamponade associated with disseminated tuberculosis. Can J Cardiol 2000; 16: 519-521.

4. Chowdhury UK, Subramaniam GK, Kumar AS, Airan B, Singh R, Talwar S, Seth S, Mishra PK, Pradeep KK, Sathia S, Venugopal P. Pericardiectomy for Constrictive Pericarditis: A Clinical, Echocardiographic, and Hemodynamic Evaluation of Two Surgical Techniques. Ann Thorac Surg 2006; 81: 522-529. 